\title{
Opening School Doors to Communities and Families: A Social Capital Perspective for Multiparty Collaboration
}

\section{Elizabeth A. Mellin}

Binghamton University, College of Community and Public Affairs

\section{Elise E. Belknap}

The Pennsylvania State University, Department of Educational Psychology, Special Education, and Counseling

Ian L. Brodie

Lake Braddock Secondary School, Burke, VA

\section{Kristen Sholes}

Brockway Area Elementary School, Brockway, PA

\begin{abstract}
Multiparty collaboration is largely acknowledged as a best practice strategy for school counselors. Although collaboration among schools, families, and communities is seen as necessary for community change and systems transformation, policies and efforts to increase collaboration in and with schools are a step ahead of theory and research. This article introduces social capital theory as a lens for school counselors who are working to transform their communities through multiparty collaboration. Practical suggestions for strengthening collaborative practice and research on multiparty collaboration are offered.
\end{abstract}

Keywords: social capital, collaboration, school counselors, communities, families

School counselors are increasingly called upon to address complex systems issues within schools and communities that impact developmental outcomes (i.e., academic, career, and personal-social) for youth. School counselors, for example, are encouraged to redefine traditional roles and responsibilities in order to better address opportunity gaps among racialethnic and socioeconomic groups (Griffin \& Steen, 2011; Trusty, Mellin, \& Herbert, 2008). Scholars are challenging school counselors to address the heteronormative and homophobic atmosphere of schools to support the underserved population of lesbian, gay, bisexual, transgender, queer, and questioning (LGBTQQ) students (Goodrich \& Luke, 2009). School 
counselors are also encouraged to advocate for the unique needs of undocumented students (Storlie \& Jach, 2012). Despite the notable efforts of school counselors in each of these areas, within the current environment of decreasing resources and overwhelming school counselorstudent ratios (American School Counselor Association [ASCA], 2013), it is clear that school counselors must collaborate with communities and families to most effectively realize positive community change and systems transformation.

Multiparty collaboration, a term used in organizational literature (Gray, 1989), describes the practice of partnerships among counselors, families, and students and is defined as ".... process through which parties who see different aspects of a problem can constructively explore their differences and search for solutions that go beyond their own limited vision of what is possible" (Gray, 1989, p.5). The goal of this type of collaboration is to address community and systemic issues (e.g., poverty, resource deficits) that have an impact on a wide range of problems (e.g., educational outcomes; Prins, 2010). Multiparty collaboration may be a particularly relevant approach for addressing community and systemic issues especially in schools and communities where demands associated with student needs are outpacing resources. Multiparty collaboration has the potential to help school counselors more effectively implement a comprehensive school counseling program through: (a) addressing the needs of young people that are interrelated across school, family, and community systems (Bemak, 2000); (b) increasing resources (Brown et al., 2006); and, (c) and igniting innovative ideas for addressing educational inequalities (Bryan, 2005; Steen \& Noguera, 2011; Trusty et al., 2008). To be effective, multiparty collaboration necessarily involves stakeholders with varying perspectives, professionals from different disciplines, and a variety of organizations (Gray, 1989; Prins, 2010).

In order to support the role of school counselors in productive community change and systems transformation, this paper will explore the benefits and challenges of multiparty collaboration and suggest the use of social capital theory as a framework for effective collaboration. Definitions for social capital are provided, including detailed descriptions of three subtypes of social capital. Challenges and dynamics for school counselors in building social capital with communities and families are also examined. Finally, the paper concludes with practical suggestions for developing social capital and suggestions for social capital grounded research that examines the impact of multiparty collaboration on child level outcomes.

\section{Multiparty Collaboration as a Professional Standard}

The school counseling profession has begun to acknowledge multiparty collaboration as a best practice strategy for community change and systems transformation (Sink, 2011). Multiple organizations and associations within the counseling profession have voiced the importance of

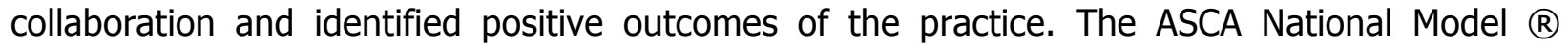
(ASCA, 2005), for example, encourages collaboration for developing comprehensive school counseling programs. The 2009 Council for the Accreditation of Counseling and Related Educational Programs (CACREP, 2009) school counseling standards also emphasize the importance of multiparty collaboration for promoting student development and delineate specific knowledge and skill outcomes for facilitating productive collaboration. Likewise, the Education Trust's Transforming School Counseling Initiative (Educational Trust, n.d.) positions

multiparty collaboration as a critical strategy for addressing educational inequalities. Lastly, the American Counseling Association Advocacy Competencies (Lewis, Arnold, House \& Toporek, 
2002) emphasize multiparty collaboration for addressing oppression and barriers to development.

National reform initiatives have similarly highlighted the importance of collaboration for addressing student needs that are interconnected across systems. The Mental Health in Schools Act of 2013 (Napolitano, 2013), for example, encourages collaboration between school and community systems to broaden efforts to promote mental health and address unmet mental health needs in school. The current Promise Neighborhoods initiative (United States Department of Education, 2012) also emphasizes multiparty collaboration among schools, families, and communities to build comprehensive programs that support the development of young people from birth through college in high need communities. These professional standards and national reform efforts signal the increasingly important role of multiparty collaboration for school counselors engaged in efforts to transform communities and systems.

Despite the increasing emphasis on collaboration by the school counseling profession, there are practical and theoretical challenges to achieving authentic multiparty collaboration. Too many preexisting commitments and responsibilities (Bryan \& Holcomb-McCoy, 2004), confusion about roles and responsibilities (Brown et al., 2006), and mistrust across systems (Trusty et al., 2008) represent just a few of the challenges to productive multiparty collaboration in real world settings. The current efforts to increase collaboration in and with schools are lacking a theoretical lens to guide and evaluate the process, making it unclear whether multiparty collaboration is in fact effective, for whom, and under what conditions. Collaboration within school counseling is in need of theory to drive understanding of the underlying assumptions and presumed benefits (Bryan, 2005; Steen \& Noguera, 2011) as well as to decrease ambiguousness within practice (Forbes, 2009).

A review of the literature on multiparty collaboration reveals a foundation largely dominated by program descriptions and other anecdotal accounts that are difficult to replicate and which could contribute to a lack of clarity for school counselors interested in partnering with communities and families (Mellin, 2009). Efforts to increase multiparty collaboration in and with schools are a step ahead of the theoretical framework that should back it (Forbes, 2009) along with the needed research that critically examines its impacts (Mellin, 2010). Given this omission, social capital theory is suggested as a useful framework for school counselors to guide their collaborative efforts.

\section{Social Capital as a Lens for Multiparty Collaboration}

Developing collaborations based on social capital theory can support community change and systems transformation because of the theory's focus on relationships, power, and the sharing of resources (Daly, Moolenaar, Bolivar, \& Burke, 2010). Social capital refers to the cumulative resources that are available to people due to a strong network of relationships between and within groups or institutions (Bourdieu, 1983; Coleman, 1988; Putnam, 2000). It is thought that social resources are just as important in meeting academic, career, and personal-social needs as physical resources (Bourdieu; Coleman; Putnam). In its simplest form, social capital has two distinct components: (a) association, which is objective and indicates that people are tied to one another in a social context; and, (b) trust, which is subjective, reciprocal, and positive in emotion (Paxton, 1999). Both components are necessary for social capital to be 
present (Schneider, 2008). Multiparty collaboration, which is about relationships within and between groups or institutions, can therefore be thought of as an enactment of social capital.

Attending to social capital within communities can be helpful in addressing disparities. Addressing the role of social capital in ameliorating the effects of poverty on educational outcomes, Warren (2005) argues, that the generation of social capital in urban communities can be particularly useful for: (a) addressing nonacademic barriers to learning such as poverty; (b) engaging the skills and assets of communities and families in meaningful ways; (c) critically examining the practices of schools and increasing their accountability for educational outcomes; and, (d) generating advocacy for providing public schools with adequate resources. Understanding the three types of social capital (Figure 1) may provide additional context for the benefits of multiparty collaboration (Forbes, 2009).

\section{Bonding Social Capital}

Bonding social capital refers to the resources that become available to individuals, due to their connections and belonging to a relatively homogenous and collective group (Putnam 2000). Bonding social capital is often observed in communities of individuals who have similar characteristics (e.g., race, faith tradition, neighborhoods, political affiliation). In terms of multiparty collaboration, bonding social capital is reflected in how connected professionals are to their home profession or school/organization. In schools, for example, bonding social capital is evident in the trust and frequent associations among school counselors, administrators, teachers, nurses, and students to work toward a common goal. Although bonding social capital can have positive effects relating to the unity of a specific group, it also has restrictive qualities in that it creates exclusivity between different groups and blocks the flow of knowledge across systems (Forbes, 2009). Ties in schools, for example, can often be so strong that they become isolated from outside ideas and resources (Woolcock \& Narayan, 2000). If this is the only form of social capital present, a school will be closed off to outside influences, rarely allowing families and the surrounding community groups to penetrate its boundaries and contribute to student outcomes. Bonding social capital might be useful for "getting by," but may not help the school in "getting ahead" (de Souza Briggs, 1997 as cited in Putnam, 2000, p.23). Bonding social capital, however, is a necessary foundation for the more powerful form of bridging social capital (Warren, Thompson, \& Saegart 2001).

\section{Bridging Social Capital}

There are distinct differences between bridging and bonding social capital; while bonding relates to the strength of in-group connections and trust, bridging, in contrast, involves reaching outside of the group to form connections with other groups of equal power and professional standing (Putnam, 2000). Groups are engaged in bridging social capital when their members connect with representatives of dissimilar groups to gain access to new or different resources (Larsen et al., 2004). This type of social capital increases a group's access to resources (Perkins, Hughey, \& Speer, 2002). It has long been thought that these incredibly important connections to other groups makes community change and systems transformations possible (Granovetter, 1973) and may be a key to productive multiparty collaboration. A school with bridging social capital, for example, has strong interrelationships between its own members and other local schools, institutions, businesses, and community services that aim to 
meet students' needs. The bridge to other groups opens up a wider pipeline of ideas and resources to help school counselors and students accomplish their academic, career, and personal-social goals. School counselors working in community schools, for example, can use ideas and resources from community organizations (e.g., health, mental health), or bridging social capital, as the vise that begins to tighten and close the opportunity gap among students from different racial and ethnic and socioeconomic groups.

\section{Linking Social Capital}

Perhaps the most powerful form of social capital is linking social capital. Linking social capital refers to the resources that become available due to relationships with groups of differing social status, wealth, and power (Cote \& Healy, 2001). In contrast to bridging social capital, which connects horizontally to groups of similar status and power, an inherent characteristic in linking social capital for groups is the vertical connections that span differences of power (Baum \& Ziersch, 2003). Linking social capital differs from bonding and bridging social capital in that it occurs when a group becomes connected to other groups with varying power and access to resources (Woolcock, 2001). This is a particularly important form of social capital for community change and systems transformation because it fosters a sense of responsibility for people beyond those in their immediate environment (Szreter, 2002). A school with linking social capital, for example, has connections to groups and institutions beyond what is considered common practice. This includes interactions with federal and state governments, universities, charity organizations, businesses and industries, as well as connecting to the valuable resources present in students and their families. Families and students are an integral part of the school despite the power differential that exists (Warren, 2005). A school with linking social capital is open to a much broader range of opportunities than are available with only bonding and bridging social capital. Home buying incentive programs such as Housing and Urban Development's Good Neighbor Next Door program (United States Department of Housing and Urban Development, 2012), which encourage teachers and other education professionals to live in high need neighborhoods, reflect the important role of linking social capital in community change and systems transformation efforts. The sense of responsibility it creates across systems (i.e. social closure) might be the missing link in addressing observed opportunity gaps across racial-ethnic and socioeconomic groups (Warren, 2005).

The current literature on social capital indicates that bonding social capital must be present before bridging and linking social capital can be realized. Bonding social capital builds trust within the school creating a strong foundation from which school counselors can operate from as they reach out to community members, families, and other stakeholders. School counselors are in a position to make adjustments within their schools in an effort to reach optimal combinations of these three types of social capital. Multiparty collaboration among schools, families, and communities may help school counselors and their partners effect community change and systems transformations.

\section{Challenges and Dynamics for Building Social Capital}

Despite the encouraging development of policy and efforts to increase multiparty collaboration in and with schools, there are real challenges to building multiparty collaboration, or social capital, in real world settings (Weist et al., 2012). Perhaps this is because the success of 
collaboration is largely dependent on relationships and relationships can be complicated (Daly et al., 2010; Prins, 2010). Social capital theory's consideration of relationships may provide school counselors with the conceptual tools they need to directly address the challenges to community change and systems transformation (Bourdieu, 1986). Three primary challenges to building bonding, bridging and linking social capital, and multiparty collaboration include: the socialization practices of professions, conflicting expectations between stakeholders, and cultural differences between stakeholders.

\section{Professional Socialization Practices}

The culture of professions established by training, mentoring, and associations can subtly influence multiparty collaboration. Although diverse professions are represented within schools, it is common at the pre-service level for training to occur in profession-specific silos with few opportunities for cross-profession learning (Ball, Anderson-Butcher, Mellin, \& Green, 2010). This silo approach to training can become a mindset that carries over into practice in schools, where professionals are often divided into categories: teachers, counselors and other student support professionals, administrators, and paraprofessionals. Moreover, professional certification bodies often require ongoing continuing education credits that are earned primarily through attendance at profession-specific conferences and workshops. These profession specific socialization rituals related to training, practice, and association can result in professional-centrism, or the belief that one profession is more legitimate than others (Pecukonis, 2008). Professional centrism can result in defensiveness and myopic choices as it can limit the ability of professionals in schools to see each other's shared values and in turn, jeopardize collaboration (Mellin, 2010).

Professional centrism is also present within school systems. Schools can and do promote profession centrism in approaches to training (e.g. profession specific in-service days), practice (e.g. policies that limit community/family access to schools), and association (e.g. school improvement teams) that include professional members of a school community, but sometimes exclude communities, families, and students from participating. As Taylor and Adelman (2000, p. 298) note, "schools are located in communities, but often are islands with no bridges to the mainland." All too often schools are expert islands, insulated from the communities in which they are embedded, unknowingly forming a barrier to the development of bridging social capital.

\section{Conflicting School and Organizational Expectations}

Efforts to bond within schools systems and bridge school and community systems are also complicated by conflicting school and organizational mandates (Lever et al., 2003). In schools, for example, communication around the needs of students is often necessarily open to allow for the flow of information critical to supporting youth development across academic, career, and personal-social domains. These expectations can cause confusion and discomfort for school counselors because of confidentiality as a standard of practice. Confidentiality is a central ethical standard for every counselor (Griffin \& Steen, 2010) and school counselors must be aware of confidentiality when communicating about and advocating on behalf of their students with other professionals in schools and community partners. A common misconception regarding confidentiality is that it is up to the discretion of the school counselor to decide what, 
when, and with whom to share information when it is in the best interest of the students. The legality and ethicality of confidentiality, however, interject the constraints school counselors face with regards to sharing information. As a result, confidentiality is often a key obstacle for school counselors in the development and maintenance of bonding, bridging, and linking social capital. Different expectations and mandates regarding communication about student needs may cause misunderstandings, erode trust, and reinforce turf issues in multiparty collaboration (Mellin \& Weist, 2011; Weist et al., 2012). When school counselors protect information that parents and students have asked to be kept confidential, for example, colleagues (administrators, teachers, etc.) may feel distrusted which can negatively affect bonding social capital. Conversely, sharing too much information about conversations with students and parents may cause stakeholders to question whether or not school counselors are going to be able keep their confidence too, once again eroding trust necessary for social capital.

In addition to differences in confidentiality mandates, conflicting expectations for allocation of already limited resources is another challenge to building bonding and bridging social capital. Many school counselors report that too many preexisting commitments and responsibilities limit their ability to participate in collaborations (Bryan \& Holcomb-McCoy, 2004, 2007). Although Epstein and Van Voorhis (2010) recommend that school counselors spend $20 \%$ of their time developing and strengthening partnerships with families and community organizations; in reality, school counselors are already facing large caseloads and expectations that they take on tasks outside of their area of responsibility (e.g., lunch/hall/bus/recess duty, assuming the role of principals when they are out of the building, monitoring detention, and/or coordinating or proctoring state standardized tests). Participating in these tasks may build bonding social capital, however, they can negatively impact the development of bridging and linking social capital necessary for successful collaboration.

Similarly, time, personnel, and monetary resource deficits overwhelm many community-based organizations. Collaborations, for example, are often challenged by fee-for-service billing mechanisms (e.g. insurance or Medicare billing) (Weist et al., 2012) that do not reimburse community partners to collaborate or consult with school professionals. These service providers are often discouraged from allocating time to services that are not "billable." For each level of social capital to develop successfully, school systems will need to evaluate expectations and think creatively about how to engage in collaboration.

\section{Cultural Differences}

One common and overarching challenge to community (bridging social capital) and family involvement (linking social capital) in schools is the issue of real and perceived cultural differences (Mellin \& Weist, 2011; Trusty et al., 2008). Distrust and disconnection between families and schools is a common concern, and a serious challenge to developing linking social capital. This is especially true in urban areas where the demographics of teachers and students can significantly differ (Bryan, 2005; Warren, 2005). Scholars have identified several issues that contribute to the distrust experienced between schools and families. Noguera (2002), for example, suggests a contributing factor to distrust between the school and families is a culturally based deficit view of students and families of color who live in poverty. Another contributing factor to the challenge of developing linking social capital between families and schools is the tendency to use white middle class family involvement in schools as an unspoken 
and unfair standard of parental involvement (Christianakis, 2011). This detrimental comparison ignores the complexities for families of color living in poverty in their relationships with school systems. Barriers such as long and less flexible work hours and a history of feeling unwelcomed and ignored in schools contribute to a different level of engagement for this group of parents (Trusty et al., 2008). Chrisitianakis (2011) further asserts that using white middle class parents as a standard for families of color living in poverty can be said to "perpetuate a tacit structural classism and racism" (p.159). From a social capital lens, these negative comparisons and perceptions restrict the development of linking social capital that can help generate advocacy for providing public schools with adequate resources.

Multiparty collaboration comes with challenges as well as benefits as it relates to community change and systems transformation. In order for school counselors to foster effective partnerships it is important to attend to the interrelationships among these three challenges and types of social capital. Without time to focus on multiparty collaboration within schools, professionals will likely practice within their professional silos and miss opportunities to integrate and maximize ideas and resources. Likewise, professional socialization practices may reinforce professional centrism and stereotypes about other professionals and thereby erode trust and association between school-based and community employed professionals, or bonding and bridging social capital. Finally, schools lacking in bonding and bridging social capital may be especially unlikely to reach out to families or community agencies who they perceive as culturally different, given trust and association difficulties within their own systems. Given these challenges, school counselors need to have practical strategies (grounded in a conceptual framework such as social capital theory) to build and maximize multiparty collaboration. Social capital considerations for school counseling practice, as well as research, follow.

\section{Social Capital Considerations for Counseling Practice and Research}

School counselors are in an ideal position to both strengthen bonds within school systems and also help schools bridge to communities and link to families because of their training in cultural, developmental, relational, and systemic frameworks (Steen \& Noguera, 2011). Social capital as a lens for multiparty collaboration can be a powerful tool for organizing school counseling practice and research centered on community change and systems transformation. Here, practical applications for school counseling practice and research are articulated using a social capital lens. Table 1 also provides a succinct summary of each type of social capital, challenges and dynamics, and associated practice and research considerations.

\section{Counseling Practice}

School counselors focusing on multiparty collaboration can use a social capital lens to organize their efforts. As previously noted, trust and association are two key components of social capital that can be used to help strengthen bonding, bridging, and linking social capital. School counselors can use a social capital lens, as well as the suggestions below to strengthen trust and association in their collaborations with school colleagues (bonding social capital), community members (bridging social capital), and families (linking social capital).

Bonding Social Capital. Professional centrism (Pecukonis, 2008), or the belief that one profession has more legitimacy than others, can threaten multiparty collaboration among school 
professionals. Moreover, professional socialization rituals related to training, practice, and association can reinforce professional boundaries in schools. Conversely, emerging research is demonstrating the powerful effects of cross-professional boundaries in schools (Daly, 2010). School counselors are ideally trained to address these challenges and build relationships. School counselors, for instance, can establish communities of practice (Wenger, McDermott, \& Snyder, 2002) focused on specific community change efforts that are inclusive of a diverse range of professionals working in schools (e.g., administrators, teachers, custodians, paraprofessionals). Communities of practice may help build association and trust across professions as individuals begin to span boundaries to work toward shared goals. Additionally, school counselors can work closely with administrators to increase opportunities for cross professional affiliation in classes and school meetings, and by supporting membership in professional organizations outside home professions. School counselors, for example, might build trust and association for teachers by offering monthly wellness groups for overtaxed teachers. Community asset mapping may also be a key strategy for school counselors focused on building bonding social capital. Kerka (2003) defines community asset mapping as "documenting the tangible and intangible resources of a community, viewing is as a place with assets to be preserved and enhanced, not deficits to be remedied" (p. 1). Mapping of schoolbased teams can help school counselors and other educators identify areas of strength as well as missed opportunities for building cross-professional association and trust (Iachini, AndersonButcher, \& Mellin, 2013). As core relationships are strengthened within schools, school counselors can also help members of the school community look beyond their school walls for additional opportunities for collaboration. Community asset mapping can help open school systems to potential opportunities for new ideas and resources to help community change and systems transformation efforts (Griffin \& Farris, 2010). School counselors can utilize and develop bonding social capital by: (1) establishing collaborative periodic professional meetings for smaller groups of counselors, teachers, and administrators to get together to discuss individual or general needs in the school; (2) creating professional development opportunities for other staff members to help them build new skills in their area of work or learn about each others areas of expertise; and, (3) meeting with school counselors in the grades above and below to discuss needs across grades in order to create a fluid counseling practice $\mathrm{K}-12$ (i.e., vertical articulation).

Bridging Social Capital. Conflicting expectations can often jeopardize multiparty collaboration across school and community systems (Lever et al., 2003). Confidentiality boundaries, use of limited resources, and fee-for service billing structures are common issues that challenge collaborations between school and community professionals (Weist et al., 2012). School counselors, with training in relational and systemic frameworks, however, are in a key position to help address and problem solve for potential areas of conflict upfront. Direct and open communication is a critical factor in supporting bridging social capital and is another aspect of multiparty collaboration school counselors are well prepared to address. As partnerships are developed with community professionals, there should be an ongoing dialogue with members of the school and partners that clearly defines roles and responsibilities and directly addresses big issues such as confidentiality. Indeed, a recent study on multiparty collaboration, found that although confidentiality restrictions posed challenges, when they were dealt with directly and prior to starting the work, collaborative relationships were strengthened (Mellin \& Weist, 2011). Use of already limited resources, and brainstorming about how to best leverage and braid existing resources, should also occur prior to initiating multiparty collaboration between school and community systems. School counselors' skills in data driven 
decision-making and accountability (Trusty et al., 2008) could also generate support for fee-forservice structures that allow billing for collaborative activities such as participation in schoolbased teams, a critical aspect of bridging social capital. Other examples of developing bridging social capital include: (1) inviting several local therapists, mental health counselors, and psychologists to consult with the counseling department to discuss needs that are being observed in the school and the community; (2) meeting with community leaders and organizations and asking them where the school system has been helpful and where the school system has been a barrier; and, (3) inviting all the resources found through community asset mapping to a "meet and greet" at the school or another neighborhood location.

Linking Social Capital. In order to effectively deal with challenges related to cultural differences, school counselors can look toward social capital theory. School counselors can do a lot of work towards making a school a more welcoming environment for families. One key role school counselors can take is educating teachers about family systems and how those ideas relate to the education of students (Ball et al., 2010). School-counselor led professional development opportunities for teachers grounded in a multigenerational transmission perspective, for example, might help create deeper understanding of how parents' experiences in schools can shape their children's educational experiences across generations. Communication is also another critical aspect of developing associations and trusting relationships between schools and families (Wong \& Hughes, 2006). Critical examination of how communications are phrased, use of language that is culturally reflective, and whether school information and paperwork is translated in appropriate languages are important for building association and trust between families and schools. There are several models available to school counselors that help foster positive communication and collaboration with families. Restorative practices (e.g., classroom circles and family decision making conferences) in schools, for example, can help establish respectful and inclusive structure for involving families in meetings regarding students' success (McCluskey, Llyod, Kane, Riddell, Stead, \& Weedon, 2008). Moore-Thomas and Day-Vines (2010) suggest that school counselors help African American communities create social capital through the development of programs and partnerships within their community. School counselors, for example, can help develop community based mentorship programs and business partnerships to help students make valuable connections as modeled by the Black Achievers Programing (Moore-Thomas and DayVines, 2010). Effective multiparty collaboration with families (i.e., linking social capital) requires recognizing cultural differences while building on the strengths of families as well as addressing their needs. Open and honest conversations about power differentials between families and schools (Warren, 2005), led by school counselors trained in cultural and systemic frameworks, are critical to building the association and trust necessary to enact linking social capital. Other examples of establishing linking social capital include: (1) establishing a school counseling advisory council representative of the makeup of the school community that gives students and parents a voice and a safe atmosphere for honest feedback and transformative resolutions; (2) holding parent coffees during non-school hours for parents to come in with their concerns, questions, or feedback that counselors respond to in order to create clarity, address concerns, and lower anxiety; and, (3) starting an evening walking program during the winter to open the school up to the community for exercise and socializing. Simply going out into the community to meet parents can help support the development of productive partnerships. 


\section{Counseling Research}

Although multiparty collaboration is considered a best practice within school counseling (Bryan \& Holcomb-McCoy, 2004; 2007; Steen \& Noguera, 2011; Trusty et al., 2008), policy and the day to day efforts to increase collaboration remain a step ahead of research on student level outcomes (Mellin, 2009). If school counseling is serious about advancing multiparty collaboration, then outcome research that highlights whether it is effective, for whom, and under what circumstances is critical. It is here that social capital theory might be most useful in advancing the role of school counselors in community change and systems transformation. Researchers, for example, could focus on the role of collaboration within schools (i.e., bonding), community organizations (i.e. bridging), and families (i.e., linking) on student outcomes. Research on each of these levels of multiparty collaboration may provide us with a broader understanding of collaboration. Research on multiparty collaboration, however, is often challenged by a lack of theoretical consistency on the meanings and types of collaboration (McIntosh, Lyon, Carlson, Everette, \& Loera, 2008), inflexible designs that do not account for contextual influences on collaboration (Ansari \& Weiss, 2006), and measurement strategies that are limited in their ability to accurately assess collaboration (Osher, 2003). Social capital theory, with its clear definitions and emphasis on relationships and resources, has the potential to effectively address many of these existing research limitations.

Social capital theory provides a strong theoretical foundation for counseling scholars interested in researching multiparty collaboration focused on community change and systems transformations. Definitions of social capital, as well as the three subtypes of social capital, can help add conceptual clarity and depth to studies of multiparty collaboration (Forbes, 2009). Social capital theory, for example, can provide concrete guidance for counseling scholars in defining collaboration to help research participants distinguish collaborative work from related activities such as communication and consultation. Additionally, the three subtypes of social capital can help sharpen the focus of researchers on types of collaborative relationships and anticipated resources resulting from those collaborations. Simultaneous consideration of collaborative relationships and related resources can help illuminate the relationship between multiparty collaboration and community change/systems transformation.

Counseling scholars may also consider flexible research designs that allow for consideration of contextual influences on multiparty collaboration. Association and trust are important aspects of social capital and, as a result, contextual influences on how these two aspects are (or are not) supported will help advance research in this area. Cross-sectional, mixed method, or action research designs are likely a better fit than the gold standard of randomized control trials (RCTs). Although RCTs may help illuminate what outcomes are impacted by multiparty collaboration, they are not flexible enough to allow for understanding of how those outcomes were achieved (Ansari \& Weiss, 2006). Additionally, less traditional but important approaches such as empowerment evaluation where researchers focus on building the capacity of individuals and organizations to assess outcomes (Fetterman \& Wandersman, 2005) may help add to the research base while simultaneously strengthening schools, families, and communities.

Advances in research methods from systems science may also help counseling scholars with the measurement of multiparty collaboration. Although few instruments are available for measuring 
collaboration in schools (Mellin, 2009), available instruments largely extrapolate conclusions about group level phenomena based on responses from individual participants.

Social network analysis, a method that can be used to quantitatively or qualitatively assess interdependent relationships among groups of people (Hatala, 2006), may provide counseling scholars with a necessary tool for accurately understanding and maximizing multiparty collaboration. This measurement approach is also flexible enough to be used with social capital theory and, given the visual output it produces, is often easily interpreted by key stakeholders. Geographic information systems (Morton, Peterson, Speer, Reid, \& Hughey, 2012) could also be used as a tool to map the proximity of community-based organizations to schools, for example, and consider relationships to intended community changes or systems transformations. In sum, methodological advancements are providing new tools for measuring collaborative relationships and may help sharpen research findings.

\section{Conclusion}

Although multiparty collaboration is frequently referenced as a best practice strategy for school counselors (Bryan, 2005; Steen \& Noguera, 2011; Trusty et al., 2008), the rhetoric that promotes collaboration has outpaced theories (Forbes, 2009) and research that should back it (Mellin, 2009). Social capital theory as a lens for multiparty collaboration can help sharpen school counseling practice and research. This theory provides clear direction for building bonding, bridging, and linking social capital in school counseling practice and results in key suggestions for adding conceptual clarity and depth to counseling research on multiparty collaboration. School counselors are encouraged to use social capital theory to guide practice and research related to collaboration among schools, families, and communities.

\section{Author Contact Information}

Elizabeth A. Mellin, email: eam20@psu.edu 


\section{References}

American School Counselor Association. (2013). Student-to-school counselor ratio. Retrieved from: http://www.schoolcounselor.org/asca/media/asca/home/ratios10-11.pdf

Ansari, W. E., \& Weiss, E. S. (2006). Quality of research on community partnerships: Developing the evidence base. Health Education Research, 21, 175-180.

Ball, A., Anderson-Butcher, D., Mellin, E. A., \& Green, J. H. (2010). Developing interdisciplinary competencies for expanded school mental health professionals: An exploratory study. School Mental Health, 2(3), 114-124.

Baum, F. E., \& Ziersch, A. M. (2003). Social capital. Journal of Epidemiology and Community Health, 57, 320-323.

Bemak, F. (2000). Transforming the role of the counselor to provide leadership in educational reform through collaboration. Professional School Counseling, 3, 323-331.

Bourdieu, P. (1986). The forms of capital. In Richardson, J.G. (Ed.), Handbook of theory and research for the sociology of education (pp. 241-258). New York: Greenwood.

Bowers, J., \& Hatch, T. (2005). The ASCA national model: A framework for school counseling programs $\left(2^{\text {nd }}\right.$ ed. $)$. Alexandria, VA: American School Counselor Association.

Brown, C., Dahlbeck, D. T., \& Sparkman-Barnes, L. (2006). Collaborative relationships: School counselors and non-school mental health professionals working together to improve the mental health needs of students. Professional School Counseling, 9, 332-335.

Bryan, J. (2005). Fostering educational resilience and achievement in urban schools through school-family-community partnerships. Professional School Counseling, 8, 219-227.

Bryan, J., \& Holcomb-McCoy, C. (2004). School counselors' perceptions of their involvement in school-family-community partnerships. Professional School Counseling,7, 162-171.

Bryan, J., \& Holcomb-McCoy, C. (2007). An examination of school counselor involvement in school-family-community partnerships. Professional School Counseling, 10, 441-454.

Gray, B. (1989). Collaborating: Finding common ground for multiparty problems. San Francisco, CA: Jossey Bass.

Christianakis, M. (2011). Parents as "help labor": Inner-city teachers' narratives of parent involvement. Teacher Education Quarterly, 38(4), 157-178.

Coleman, J. S. (1988). Social capital in the creation of human capital. American Journal of Sociology, 94, S95-S120.

Cote, S., \& Healy, T. (2001). The Well-Being of Nations: The Role of Human and Social Capital. Organisation for Economic Co-operation and Development, Paris. 
Daly, A. J. (2010). Mapping the terrain: Social network analysis and educational change. In A.J. Daly (Ed.), Social network theory and educational change (pp. 1-16). Cambridge, MA: Harvard Education Press.

Daly, A. J., Moolenaar, N. M., Bolivar, J. M., \& Burke, P. (2010). Relationships in reform: the role of teachers' social networks. Journal of Educational Administration, 48(3), 359-391.

Education Trust National Center for Transforming Counseling (n.d.). [Graph illustration]. The new vision for school counselors: Scope of the work. Retrieved from http://www.edtrust.org/dc/tsc/vision.

Epstein, J. L., \& VanVoorhis, F. L. (2010). School counselor's roles in developing partnerships with families and communities for student success. Professional School Counseling, 14, $1-14$.

Fetterman, D. M., and Wandersman, A. (2005). Empowerment evaluation principles in practice. New York: Guilford Publications.

Forbes, J. (2009). Redesigning children's services: Mapping interprofessional social capital. Journal of Research in Special Educational Needs, 9(2), 122-132. doi:10.1111/j.1473802.2009.01125x

Goodrich, K. M., \& Luke, M. (2009). LGBTQ responsive school counseling. Journal of LGBT Issues in Counseling, 2, 113-117. doi: 10.1080/15538600903005284

Granovetter, M. (1973). The strength of weak ties. American Journal of Sociology, 78, 13601380.

Griffin, D., \& Farris, A. (2010). School counselors and collaboration: Finding resources through community asset mapping. Professional School Counseling, 13, 248-256.

Griffin, D., \& Steen, S. (2011). A social justice approach to school counseling. Journal for Social Action in Counseling and Psychology, 3(1), 74-85.

Hatala, J. P. (2006). Social network analysis in human resource development: A new methodology. Human Resource Development Review, 5, 45-71.

Iachini, A. L., Anderson-Butcher, D., \& Mellin, E. A. (2013). Exploring best practice teaming strategies among school-based teams: Implications for school mental health practice and research. Advances in School Mental Health Promotion, 6(2), 139-154.

Kerka, S. (2003). Community asset mapping. Clearinghouse on Adult, Career, and Vocational Education: Trends and Issues Alert, 47, 1-2.

Larsen, L., Harlan, S. L., Bolin, B., Hackett, E. J., Hope, D., Kirby, A., Nelson, A., Rex, T. R., \& Wolf, S. (2004). Bonding and bridging: Understanding the relationship between social capital and civic action. Journal of Planning Education and Research, 24, 64-77. 
Lever, N. A., Adelsheim, S., Prodente, C., Christodulu, K. V., Ambrose, M., Schlitt, J., \& Weist, M. D. (2003). System, agency, and stakeholder collaboration to advance mental health programs in schools. In Weist, M. D., Evans, S., \& Lever, N. (Eds.), Handbook of school mental health: Advancing practice and research (pp. 107-118). New York: Kluwer Academic/Plenum Publishers.

Lewis, J. A., Arnold, M. S., House, R., \& Toporek, R. L. (2002). Advocacy competencies [PDF document]. Retrieved from http://www.counseling.org/knowledge-center/competencies

McIntosh, J. M., Lyon, A. R., Carlson, G. A., Everette, C. D. B., Loera, S. (2008). Measuring the mesosytem: A survey and critique of approaches to cross setting measurement for ecological research and models of collaborative care. Families, Systems, \& Health, 26, 86-104.

Mellin, E. A. (2009). Unpacking interdisciplinary collaboration in expanded school mental health: A conceptual model for developing the evidence base. Advances in School Mental Health Promotion, 2, 4-14.

Mellin, E. A. (2010). Interprofessional social capital: A lens for collaboration between school counselors and community psychologists. The Community Psychologist, 43(2), 23-25.

Mellin, E. A. \& Weist, M. D. (2011). Exploring school mental health collaboration in an urban community: A social capital perspective. School Mental Health, 3, 81-92.

McCluskey, G., Lloyd, G., Kane, J., Riddell, S., Stead, J., \& Weedon, E. (2008). Can restorative practices in schools make a difference?. Educational Review, 60(4), 405-417.

Moore-Thomas, C., \& Day-Vines, N. L. (2010). Culturally competent collaboration: School counselor collaboration with African American families and communities. Professional School Counseling, 11, 159-165.

Morton, C. M., Peterson, A., Speer, P. W., Reid, R. J., \& Hughey, J. (2012). Applying geographic information systems to community research. In Jason, L., \& Glenwick, D. S. (Eds.), Methodological approaches to community-based research (pp.205-220). Washington, DC: American Psychological Association.

Napolitano, G. F. (2013). Mental health in schools act. Retrieved from: http://napolitano.house.gov/legislative-work/mental-health-schools-act

Noguera, P. A. (2002). Beyond size: The challenge of high school reform. Educational Leadership, 59(5), 60-63.

Osher, D. M. (2003). Creating comprehensive and collaborative systems. Journal of Child and Family Studies, 11, 91-99.

Paxton, P. (1999). Is social capital declining in the United States? A multiple indicator assessment. American Journal of Sociology, 105, 88-127. 
Pecukonis, E. (2008). Reducing barriers to interprofessional training: Promoting interprofessional cultural competence. Journal of Interprofessional Care, 22, 417-428.

Perkins, D. D., Hughey, J., \& Speer, P. W. (2002). Community psychology perspectives on social capital theory and community development practice. Journal of the Community Development Society, 33(1), 33-52.

Prins, S. (2010). From competition to collaboration: Critical challenges and dynamics in multiparty collaboration. The Journal of Applied Behavioral Science, 46(3), 281-312. doi: $10.1177 / 0021886310369885$

Putnam, R. D. (2000). Bowling alone: The collapse and revival of American community.New York: Simon \& Schuster.

Schneider, J. (2008). Social capital, civic engagement and trust. Anthropologica, 50, 425-428.

Sink, C. (2011). Editorial introduction: School-wide responsive services and the value of collaboration. Professional School Counseling, 14(3), ii-iv.

Steen, S. \& Noguera, P. A. (2011). A broader and bolder approach to school reform: Expanded partnership roles for school counselors. Professional School Counseling, 14, 42-52.

Storlie, C. A. \& Jach, E. A. (2012). Social justice collaboration in schools: A model for working with undocumented Latino students. Journal for Social Action in Counseling and Psychology, 4(2), 99-116.

Szreter, S. (2002) The state of social capital: Bringing back in power, politics and history. Theory and Society, 31, 573-621.

Taylor, L. \& Adelman, H. S. (2000). Connecting schools, families, and communities. Professional School Counseling, 3(5), 298-307.

Trusty, J., Mellin, E. A., \& Herbert, J. T. (2008). Working to close historical achievement gaps: Roles and tasks of elementary school counselors. Elementary School Journal, 108, 407421.

United States Department of Education, Office of Innovation and Improvement. (2012). Promise neighborhoods, program description. Retrieved from http://www2.ed.gov/programs/promiseneighborhoods/index.html\#description

United States Department of Housing and Urban Development. (2012). About good neighbor next door. Retrieved from http://portal.hud.gov/hudportal/HUD?src=/program_offices/housing/sfh/reo/goodn/gnd abot

Warren, M. R. (2005). Communities and schools: A new view of urban education reform. Harvard Educational Review, 75, 133-139. 
Warren, M. R., Thompson, J. P., \& Saegert, S. (2001). The role of social capital in combating poverty. In Saegert, S., Thompson, J.P. \& Warren, M.R. (Eds.)., Social capital and poor communities (pp. 1-28). New York: Russell Sage Foundation.

Weist, M. D., Mellin, E. A., Stiegler, K. L., Lever, N., Haber, N., \& Blaber, C. (2012). Challenges to collaboration in school mental health and strategies for overcoming them. Journal of School Health, 82, 97-105.

Wenger, E., McDermott, R., \& Snyder, W. M. (2002). Cultivating communities of practice: $A$ guide to managing knowledge. Boston, MA: Harvard Business School Press.

Wong, S. W. \& Hughes, J. N. (2006). Ethnicity and language contributions to dimensions of parental involvement. School Psychology Review, 35, 645-662.

Woolcock, M. (2001). The place of social capital in understanding social and economic outcomes. Canadian Journal of Policy Research, 2(1), 1-17.

Woolcock, M. \& Narayan, D. (2000). Social capital: Implications for development theory, research, and policy. The World Bank Research Observer, 15(2), 225-249. 
Table 1

Types of Social Capital and Selected Challenges, Practice Strategies, and Research Considerations

\begin{tabular}{|c|c|c|c|}
\hline $\begin{array}{l}\text { Type of } \\
\text { Social } \\
\text { Capital }\end{array}$ & Selected Challenges & Practice Strategies & $\begin{array}{l}\text { Research } \\
\text { Considerations }\end{array}$ \\
\hline Bonding & $\begin{array}{l}\text { Profession-centrism (i.e., } \\
\text { exclusive ties to home } \\
\text { profession and/or school) }\end{array}$ & $\begin{array}{ll}\text { - } & \text { Communities of practice } \\
\text { - } & \text { Opportunities for cross- } \\
\text { professional training, } \\
\text { - } \quad \text { Wellness groups for } \\
\text { teachers } \\
\text { - } \quad \text { Team mapping } \\
\text { - } \text { Community asset } \\
\text { mapping }\end{array}$ & $\begin{array}{l}\text { Theoretical } \\
\text { Foundations: } \\
\text { - Use of social capital } \\
\text { theory to sharpen } \\
\text { focus of research } \\
\text { and considerations } \\
\text { of different types of } \\
\text { multiparty } \\
\text { collaborations }\end{array}$ \\
\hline Bridging & $\begin{array}{l}\text { Conflicting school and } \\
\text { organizational } \\
\text { expectations (e.g., } \\
\text { confidentiality, resource } \\
\text { allocation, fee-for-service } \\
\text { billing) }\end{array}$ & $\begin{array}{l}\text { Direct and open } \\
\text { communication about big } \\
\text { issues before beginning } \\
\text { collaboration } \\
\text { - Brainstorming leveraging } \\
\text { and blending of limited } \\
\text { resources } \\
\text { - Evaluation of impact of } \\
\text { multiparty collaboration } \\
\text { and advocacy for } \\
\text { changes to fee-for- } \\
\text { service billing structures }\end{array}$ & $\begin{array}{l}\text { Research Designs: } \\
\text { - Use of flexible } \\
\text { designs such as } \\
\text { cross-sectional, } \\
\text { mixed-method, } \\
\text { empowerment } \\
\text { evaluation, or } \\
\text { action research that } \\
\text { allow for } \\
\text { understanding how } \\
\text { outcomes are } \\
\text { achieved. }\end{array}$ \\
\hline Linking & $\begin{array}{l}\text { Cultural differences (i.e., } \\
\text { mistrust relating to class } \\
\text { and cultural differences } \\
\text { between families and } \\
\text { schools) }\end{array}$ & 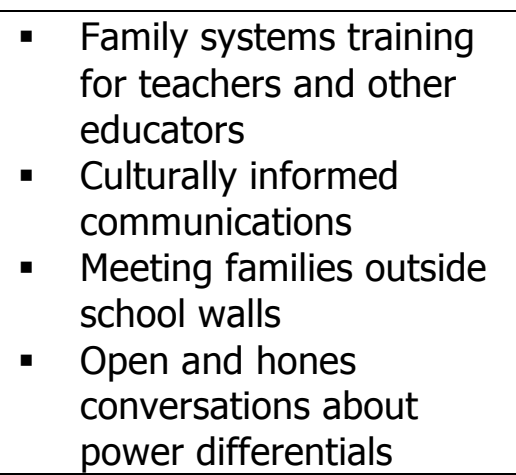 & $\begin{array}{l}\text { Methods: } \\
\text { - Use of methods } \\
\text { such as social } \\
\text { network analysis } \\
\text { and GIS to more } \\
\text { accurately assess } \\
\text { interdependent } \\
\text { relationships } \\
\text { among groups of } \\
\text { people. }\end{array}$ \\
\hline
\end{tabular}

